\title{
WHEAT YIELD AND PHYSICAL PROPERTIES OF A BROWN LATOSOL UNDER NO-TILLAGE IN SOUTH-CENTRAL PARANÁ(1)
}

\author{
Luiz Fernando Machado Kramer ${ }^{(2)}$, Marcelo Marques Lopes Müller ${ }^{(3)}$, Cássio Antônio

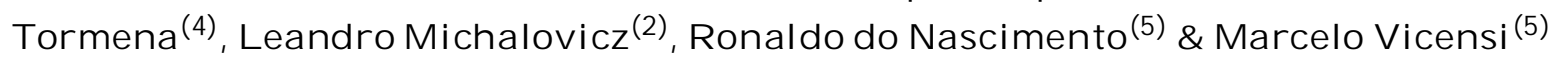

\section{SUMMARY}

Soil management influences the chemical and physical properties of soil. Chemical conditions have been thoroughly studied, while the role of soil physical conditions regarding crop yield has been neglected. This study aimed to analyze the wheat yield and its relationship with physical properties of an Oxisol under notillage (NT). The study was carried out between 2010 and 2011, in Reserva do Iguaçu, State of Paraná, Brazil, on the Campo Bonito farm, after 25 years of NT management. Based on harvest maps of barley (2006), wheat (2007) and maize (2009) of a plot (150 ha), zones with higher and lower yield potential ( $\mathrm{Z1}$ and $\mathrm{Z2}$, respectively) were identified. Sampling grids with 16 units $(50 \times 50$ m) and three sampling points per unit were established. The wheat grain yield (GY) and water infiltration capacity (WIC) were evaluated in 2010 . Soil samples with disturbed and undisturbed structure were collected from the $0.00-0.10$ and $0.10-0.20 \mathrm{~m}$ layers. The former were used to determine soil organic carbon (Corg) levels and the latter to determine soil bulk density (BD), total porosity (TP), macroporosity (Mac), and microporosity (Mic). Soil penetration resistance (PR) and water content (SWC) were also evaluated. The wheat GY of the whole plot was close to the regional average and the yield between the zones differed significantly, i.e. $22 \%$ higher in $\mathrm{Z1}$ than in Z2. No significant variation in Mic was observed between zones, but Z1 had higher Corg levels, SWC, TP and Mac and lower BD than Z2 in both soil layers, as well as a lower PR than $\mathrm{Z2}$ in the 0.00-0.10 m layer. Therefore, soil physical conditions were more restrictive in $\mathrm{Z2}$, in agreement with wheat yield and zone

\footnotetext{
(1) Part of the Master's thesis of the first author, at the South-Central State University - UNICENTRO, Postgraduate Course in Agronomy. Received for publication on July 27, 2012 and approved on June 7, 2013.

(2) Doctoral student at the Maringá State University - UEM, Postgraduate course in Agronomy. Av. Colombo 5790. CEP 87020900 Maringá (PR), Brazil. E-mail: luizfernandokramer@gmail.com, leandroguarapuava@hotmail.com

(3) Associate Professor, Department of Agronomy, UNICENTRO. Rua Simeão Camargo Varella de Sá, 3. CEP 85040-080 Guarapuava (PR), Brazil. E-mail: mmuller@unicentro.br

(4) Associate Professor, Department of Agronomy, UEM. CNPq Scholarship. E-mail: catormena@uem.br

(5) Master Student at UNICENTRO, Postgraduate Course in Agronomy. E-mail: ronaldosc18@hotmail.com; marcelo_vicensi@hotmail.com
} 
yield potential defined $a$ priori, based on the harvest maps. Soil WIC in Z1 was significantly higher (30\%) than in Z2, in agreement with the results of TP and Mac which were also higher in $\mathrm{Z1}$ in both soil layers. The correlation analysis of data of the two layers showed a positive relationship between wheat GY and the soil properties TP, SWC and WIC.

Index terms: soil physical quality, wheat yield, correlation.

\title{
RESUMO: PRODUTIVIDADE DO TRIGO E ATRIBUTOS FÍSICOS DE UM LATOSSOLO BRUNO SOB PLANTIO DIRETO NO CENTRO-SULDO PARANÁ
}

\begin{abstract}
O manejo influencia atributos químicos e físicos do solo; entretanto, os químicos têm sido mais estudados, negligenciando-se a relevância da física do solo para a produtividade das culturas. Os objetivos deste trabalho foram avaliar a produtividade do trigo e caracterizar a sua relação com os atributos físicos de um Latossolo Bruno, sob sistema plantio direto (NT). $O$ estudo foi realizado entre 2010-2011 em Reserva do Iguaçu, Paraná, em um dos talhões da fazenda Campo Bonito, com 25 anos de NT. Os mapas de colheita de cevada (2006), trigo (2007) e milho (2009) permitiram identificar as zonas Z1 (potencial produtivo maior) e Z2 (potencial produtivo menor), em que se estabeleceram malhas amostrais com 16 unidades de $50 \times 50$ m e três pontos de amostragem por unidade. Em 2010, avaliaram-se a produtividade de grãos (GY) do trigo e a capacidade de infiltração de água no solo (WIC). Amostras de solo com estrutura deformada e indeformada foram coletadas nas camadas de 0,00-0,10 e 0,10$0,20 \mathrm{~m}$. As primeiras serviram para determinar o teor de carbono orgânico (Corg) e as últimas para determinar: densidade do solo (BD), porosidade total do solo (TP), macroporosidade (Mac) e microporosidade (Mic). Avaliaram-se, também, a resistência do solo à penetração (PR) e o conteúdo de água do solo (SWC). A GY do trigo no talhão foi próxima da média regional e houve diferença significativa de rendimento entre zonas, sendo $22 \%$ superior em $Z 1$ em relação a $Z 2$. Não houve variação significativa da Mic entre as zonas do talhão; $Z 1$ apresentou teores de Corg, SWC, TP e Mac maiores e BD menor que Z2, nas duas camadas de solo avaliadas, além de PR menor que Z2, na camada de 0,00-0,10 m, havendo, portanto, condição física de solo mais restritiva em $Z 2$, condizente com os resultados de produtividade do trigo e potencial produtivo delimitado a priori, a partir dos mapas de colheita. A WIC foi significativamente maior (30\%) em Z1 que em Z2, em acordo com os resultados de TP e Mac, também maiores em Z1, nas duas camadas de solo. Considerando-se essas duas camadas, a análise de correlação permitiu destacar relações positivas entre a GY do trigo e TP, SWCe WIC.
\end{abstract}

Termos de indexação: qualidade física do solo, rendimento do trigo, correlação.

\section{INTRODUCTION}

Brazil has the world's second largest area under no-tillage (NT) agriculture, with a total of more than 25.5 million hectares under this management (Derpsch et al., 2010). Considered one of the greatest advances achieved in Brazilian agriculture, NT is primarily a conservation system, because it significantly reduces water erosion and enhances the organic carbon stocks in soils (Corg) (Lopes et al., 2004), also increasing the efficiency in terms of storage and recycling of water and nutrients and biological activity (Ceretta et al., 2002; Resende, 2011).

On the other hand, soil management with NT may cause a reduction in soil porosity and an increase in soil bulk density (BD) (Tormena et al., 2002), greater penetration resistance (PR) and decreased soil permeability (Silva et al., 2009), which can reduce the availability of water and nutrients to plants and affect the crop performance (Giarola et al., 2009). Therefore, the soil physical quality needs to be monitored, to identify the best management practices to maintain the sustainability of agricultural systems (Beutler et al., 2009).

Most efforts regarding monitoring, however, have been based on soil chemical properties, because the collection of information related to soil physics is more difficult. In this case, according to Santi (2007), sampling would be more reasonable if it were directed or if it addressed areas with high and low crop yield, which should be as small and homogeneous as the technical level and costs allow (Dodermann \& Ping, 2004). To characterize the interrelation between the yield potential of a wheat crop and soil properties, Mulla \& Bhatti (1997) divided a study area in units of low, moderate and high yield.

According to Guimarães (2011), the loss of soil physical quality is evidenced by a reduction of water 
infiltration in the soil, increased erosion susceptibility and mechanical impediments to root penetration. As it is related to plant growth and is easily and rapidly determined, PR has been used as soil compaction indicator (Mercante et al., 2003), with critical values for plants established between 1.5 and $4.0 \mathrm{MPa}$, depending on the species, while a value of $2.0 \mathrm{MPa}$ is generally accepted as the limit above which there is an impediment to root growth of agricultural crops (Imhoff et al., 2000).

In turn, BD is directly related to soil water retention and infiltration, root development, gas exchange, and soil susceptibility to erosion, and constitutes the most direct quantitative measurement of soil compaction (Reichert et al., 2007). Critical values of BD for different textural soil classes were proposed by Reinert \& Reichert (2001): $1.30 \mathrm{Mg} \mathrm{m}^{-3}$ for soils above $55 \%$ clay; $1.50 \mathrm{Mg} \mathrm{m}^{-3}$ for soils between 20 and $55 \%$ clay; and $1.80 \mathrm{Mg} \mathrm{m}^{-3}$ for soils below $20 \%$ clay.

Water infiltration into the soil is related to the structural arrangement of the particles and, therefore, to the BD and total porosity (TP) of the soil. Measuring the water infiltration capacity (WIC) into the soil, in turn, determines the amount of water (irrigation, rain) an area can tolerate without occurrence of surface flow (Pott et al., 2005), so WIC is an important indicator of soil conditions for plant growth and of water, nutrient and soil loss. According to Islan \& Weil (2000), permeability to water reflects the structural quality and stability of a soil. Studying no-tillage fields, Santi (2007) concluded that water infiltration into the soil was one of the soil physical properties with greatest influence on soybean, wheat and maize yield.

Inversely proportional to $\mathrm{BD}$, soil TP is divided into microporosity (Mic), representing pores in which water is retained for plant absorption, and macroporosity (Mac), representing pores from which water drains and, therefore, gas exchange occurs (Kiehl, 1979). Increasing BD values result in modifications of the soil porous spaces, arising from TP reduction, normally at the expense of Mac, which may reduce gas exchange between the soil and atmosphere and increase soil PR (Letey, 1985; Blainski et al., 2009).

Soil Mic is highly influenced by the texture and Corg level and weakly influenced by traffic of agricultural machinery (Silva \& Kay, 1997). Soil Mac, which is altered by compaction, may be used to evaluate the performance of soil management systems in relation to crop yield, since values less than $0.10 \mathrm{~m}^{3} \mathrm{~m}^{-3}$ of air-filled porosity limit root growth (Tormena et al., 1998). According to Araújo (2004), porosity is an indicator of soil alterations caused by agricultural use, reflecting the soil quality, for directly affecting the water infiltration velocity, gas exchange, microbial life, and root growth.

This study was carried out on a Brown Latosol (Oxisol) under no-tillage management, on a wheat field in south-central Paraná, to investigate wheat yield and its relation with properties of soil physical quality.

\section{MATERIAL AND METHODS}

The study was conducted between 2010 and 2011 on the Campo Bonito farm, a 5,000 ha property in the Reserva do Iguaçu, Paraná State. For at least 25 years, the no-tillage management had been used and as of 2005, precision agriculture techniques were adopted, based on yield maps. The climate is Cfb (Köppen), with a mild summer and severe frosts in winter (IAPAR, 2000). Pluvial precipitation data from the meteorological station of the Instituto Agronômico do Paraná (IAPAR, 2011), located in Guarapuava ( $100 \mathrm{~km}$ from the field), are shown in figure 1, together with the precipitation recorded on the farm (pluviometer) in 2010. According to the soil map of the State of Paraná (Bhering \& Santos, 2008), the area is located in the mapping unit LBd5, with dystroferric Brown Latosols (Oxisols).

In May 2010, one of the plots (150 ha) was selected and the soil sampled (0.00-0.20 m layer), to determine the chemical fertility and texture (Table 1). Considering the difficulties with soil sampling and laboratory analysis of soil physical properties for areas of many hectares, and in agreement with Mulla \& Bhatti (1997) and Santi (2007), the available yield maps were used to separate two sampling zones in the plot, Z1 and Z2 (Table 2), with distinct yield potential, also aiming to avoid the restriction of range (restriction of variability) of the variables, which could impair the correlation analysis (Lira, 2004).

To allow comparisons, the selection of Z1 and Z2 considered similarities in terms of landscape (shoulder position) and slope $(\leq 5 \%)$. The crop rotations, managed homogeneously in both zones, consisted of: two soybean crops for each crop of maize in summers; in the winter, wheat and barley were interspersed with oats for grazing. The occurrence of these phases is variable, depending on the target profitability. A rotation grazing system was used in the winter, with 7 days of grazing and 28 days of pasture regrowth in paddocks subdivided by electric fencing. When the plants had sufficient biomass, the animals grazed again for 7 days, rotating to neighboring paddocks at the end of each grazing period.

As the crop to be evaluated in 2010 was wheat, only the yield maps of grass crops were used to delimit Z1 and Z2 (Table 2): barley (2006), wheat (2007) and maize (2009). Barley (BRS 195) and wheat (cv. Ônix) were sown in a row spacing of $0.17 \mathrm{~m}$, in stands of 280 plants $\mathrm{m}^{-2}$ and fertilized with $280 \mathrm{~kg} \mathrm{ha}^{-1}$ of the NPK 08-30-20 fertilizer and $100 \mathrm{~kg} \mathrm{ha}^{-1}$ of nitrogen $(\mathrm{N})$, with urea topdressing at tillering. Maize (Pioneer 30R50) was sown in a row spacing of $0.70 \mathrm{~m}, 75,000$ plants ha-1 and fertilized with $350 \mathrm{~kg} \mathrm{ha}^{-1}$ of NPK 
Table 1. Soil fertility and particle size analysis* of the plot at the beginning of the study

\begin{tabular}{|c|c|c|c|c|c|c|c|c|c|c|}
\hline Corg & $\mathbf{P}^{(\mathbf{1})}$ & $\mathrm{pH}\left(\mathrm{CaCl}_{\mathbf{2}}\right)$ & $\mathbf{A l}^{3+}$ & $\mathbf{H}+\mathbf{A l}$ & $\mathrm{Ca}^{2+}$ & $\mathrm{Mg}^{2+}$ & $\mathbf{K}^{+}$ & Sand & Silt & Clay \\
\hline $\mathrm{g} \mathrm{dm} \mathrm{m}^{-3}$ & $\mathrm{mg} \mathrm{dm} \mathrm{m}^{-3}$ & & & 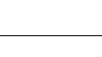 & $\mathrm{nol}_{\mathrm{c}} \mathrm{dn}$ & & & & $\mathrm{g} \mathrm{kg}^{-1}$ & \\
\hline 32 & 6.0 & 5.0 & 0.27 & 6.20 & 1.92 & 0.80 & 0.38 & 45 & 234 & 721 \\
\hline
\end{tabular}

(1) Mehlich-1. *According to Pavan et al. (1992) and Embrapa (1997), respectively.

Table 2. Descriptive statistics of the data from the yield maps of barley (2006), wheat (2007) and maize (2009) in the zones of the plot selected for the study

\begin{tabular}{|c|c|c|c|c|c|}
\hline Zone & Mean & Minimum & Maximum & $\mathbf{S D}^{(1)}$ & $\mathbf{C V}^{(2)}$ \\
\hline & \multicolumn{5}{|c|}{$\mathrm{kg} \mathrm{ha}^{-1}$} \\
\hline & \multicolumn{5}{|c|}{ Barley 2006} \\
\hline $\mathrm{Z} 1$ & 3,462 & 1,750 & 4,995 & 650 & 19 \\
\hline $\mathrm{Z} 2$ & 3,126 & 1,752 & 4,998 & 687 & 22 \\
\hline \multicolumn{6}{|c|}{ Wheat 2007} \\
\hline $\mathrm{Z} 1$ & 3,312 & 1,750 & 4,999 & 761 & 23 \\
\hline $\mathrm{Z} 2$ & 1,491 & 1,000 & 3,808 & 327 & 22 \\
\hline \multicolumn{6}{|c|}{ Maize 2009} \\
\hline $\mathrm{Z} 1$ & 10,218 & 4,038 & 13,709 & 1,811 & 18 \\
\hline $\mathrm{Z} 2$ & 7,532 & 4,857 & 13,349 & 1,150 & 15 \\
\hline
\end{tabular}

${ }^{(1)} \mathrm{SD}$ : standard deviation; ${ }^{(2)} \mathrm{CV}$ : coefficient of variation.

10-26-24 fertilizer and topdressed with $200 \mathrm{~kg} \mathrm{ha}^{-1} \mathrm{~N}$ (urea) at the eight-leaf stage. The phytosanitary control and fertilization were performed according to the official recommendations for the crops (Embrapa, 2008a,b; 2009).

A regular grid with 16 sampling units of $50 \times 50$ $\mathrm{m}$ was established in each zone, covering 8 ha of the total plot. In each unit, a diagonal line was set up with three equidistant points defined for sampling, making up 96 points in the plot. The evaluated wheat crop (cv. BRS Guamirim) was sown in June 2010, in a row spacing of $0.17 \mathrm{~m}$, in stands of 280 plants $\mathrm{m}^{-2}$ fertilized with $330 \mathrm{~kg} \mathrm{ha}^{-1}$ of 09-25-24 NPK fertilizer and topdressed with $100 \mathrm{~kg} \mathrm{ha}^{-1} \mathrm{~N}$ (urea) at tillering. Yield was determined in November 2010 after manual harvest of an area of $1 \mathrm{~m}^{2}$ per sampling point. After drying and threshing, the grains were weighed and the moisture content was corrected to $130 \mathrm{~g} \mathrm{~kg}^{-1}$.

The soil was evaluated at each point. Using a constant head permeameter (model IAC), which operates on the Mariotte siphon principle, WIC was determined using a controlled hydraulic head of 0.06 $\mathrm{m}$ at a depth of $0.10 \mathrm{~m}$, in holes opened with a $0.06 \mathrm{~m}$ diameter auger. Measures were taken at $1 \mathrm{~min}$ intervals until constant flow was achieved, i.e. after five consecutive readings of the same value. WIC was calculated using equation 1 (Pott \& De Maria, 2003):

$$
W I C=q \times 60 \times\left(\frac{D p^{2}}{D o^{2}+(4 \times D o \times H)}\right)
$$

where $q$ is the constant water flow of the permeameter $\left(\mathrm{mm} \mathrm{min}{ }^{-1}\right), \mathrm{Dp}$ is the permeameter diameter $(\mathrm{mm})$, Do is the soil hole diameter ( $\mathrm{mm}$ ) and $\mathrm{H}$ is the hydraulic head ( $\mathrm{mm}$ ).

The soil was also sampled at each point, with disturbed (auger) and undisturbed soil structure (volumetric rings of $0.0001 \mathrm{~m}^{3}$ ) in the 0.00-0.10 and 0.10-0.20 m layers. The disturbed samples were used to determine the Corg levels, according to Pavan et al. (1992). The undisturbed samples were prepared with nylon cloth fixed to the lower end of the rings and saturated in water for $48 \mathrm{~h}$, weighed and left to drain on a tension table at $-0.006 \mathrm{MPa}$. After drainage, they were weighed again and the volumetric water content was calculated to determine the soil Mic (Embrapa, 1997). Then, the soil was dried to constant weight at $\pm 105^{\circ} \mathrm{C}$. The soil dry mass and volume (ring volume) were used to determine BD (Blake \& Hartge, 1986).

The TP was obtained using the relation between $\mathrm{BD}$ and soil particle density (Dp) (Danielson \& Sutherland, 1986), while soil Mac was obtained by the difference between TP and Mic. Soil Dp was determined by the volumetric flask method with ethyl alcohol (Embrapa, 1997), using the soil from the core ring samples. In July 2011, soil PR was evaluated with a Falker ${ }^{\circledR}$ penetrometer at each $0.01 \mathrm{~m}$ (Tormena \& Roloff, 1996) to a depth of $0.20 \mathrm{~m}$, and the means were calculated for the $0.00-0.10$ and 0.10 $0.20 \mathrm{~m}$ layers. Concomitantly, soil samples were collected with an auger from the same layers to determine the soil water content (SWC) (Embrapa, 1997). All determinations were performed at the Soil and Plant Nutrition Laboratory of the South-Central State University - UNICENTRO.

Data were subjected to descriptive statistics and to a normality test. Averages per zone and depth were compared by the $t$-test for independent samples, using the ASSISTAT (2011) package. Simple linear correlation analysis between variables was performed using the SPSS18 package (SPSS, 2009).

\section{RESULTS AND DISCUSSION}

The yield of the wheat crop evaluated in 2010 is shown in table 3. According to Warrick \& Nielsen (1980), the coefficient of variation (CV) can be classified into low $(\leq 12 \%)$, moderate $(12 \leq \mathrm{CV} \leq 62 \%)$ or high 
(>62\%); thus, the variability of the wheat yield on the plot was considered moderate $(27 \%)$. At the regional level of Guarapuava-PR, were the farm is located, the average wheat yield is $3,100 \mathrm{~kg} \mathrm{ha}^{-1}$ (Maggian et al., 2010), i.e., the mean plot yield was very close to the regional average. There was a significant difference between Z1 and Z2, confirming the difference observed a priori on the yield maps (Table 2). The yield in $\mathrm{Z} 1$ was $22 \%$ higher than in Z2. The zones had similar minimum, but differed in the maximum values.

The results for soil Corg, PR, SWC, BD, TP, Mic and Mac are shown in table 4. Low variability was recorded for Corg in both layers (0.00-0.10 and 0.10$0.20 \mathrm{~m}$ ) and mean values were considered very high, according to Serrat et al. (2006), indicating an

Table 3. Descriptive statistics and Student's $t$-test for wheat yield, evaluated in 2010 in the zones of the plot selected for the study

\begin{tabular}{ccccccc}
\hline Zone & Mean & Minimum & Maximum & $\mathbf{S D}^{(\mathbf{1})}$ & $\mathbf{C V}^{(\mathbf{2})}$ \\
\cline { 2 - 6 } & \multicolumn{5}{c}{$\mathrm{kg} \mathrm{ha}^{-1}$} \\
Z1 & $3,431 \mathrm{~A}^{*}$ & 1,326 & 5,887 & 762 & 22 \\
Z2 & $2,676 \mathrm{~B}$ & 1,379 & 4,799 & 721 & 27 \\
Plot mean & 3,054 & 1,326 & 5,887 & 829 & 27 \\
\hline
\end{tabular}

${ }^{(1)} \mathrm{SD}$ : standard deviation; ${ }^{(2)} \mathrm{CV}$ : coefficient of variation. $*$ Means followed by different letters indicate significant difference $(\mathrm{p}<0.05)$ by Student's t-test. adequate maintenance of soil organic matter levels in the plot by the management system, also consistent with the cold and humid climate conditions of the region $(\mathrm{Cfb})$. There was a significant difference between $\mathrm{Z} 1$ and $\mathrm{Z} 2$ in both soil layers, with 6.1 and $12.6 \%$ higher Corg levels, respectively, in 0.00-0.10 and $0.10-0.20 \mathrm{~m}$ of Z1. In both zones, Corg was higher in the upper layer, which is explained by the use of NT for more than 25 years, without straw incorporation, which is left as mulch on the soil surface.

There was low variability in PR in both soil layers, contrasting with the observations of Cherubin et al. (2011), who reported a CV > 62\% for PR in a dystrophic Red Latosol (Oxisol) under NT, but close to the values observed by Tavares Filho et al. (2012) in a eutroferric Red Latosol under NT, with a CV $=22 \%$ for PR. The low variability in this study may be due to the high number of observations (96) in the plot. In comparison, Tavares Filho \& Ribon (2008) found that the number of representative samples required to ensure data accuracy (acceptable variability) of $\mathrm{PR}$ was equal to or greater than 15 under NT and perennial crops and equal to or greater than 20 under conventional soil management.

Regarding the $0.00-0.10 \mathrm{~m}$ layer, $\mathrm{PR}$ was higher in Z2 than Z1 and although soil SWC was lower in this zone, which could overestimate PR (Busscher et al., 1997), BD was also higher in Z2. According to Busscher (1990) and Busscher et al. (1997), inappropriate management may increase PR and BD,

Table 4. Descriptive statistics and Student's $t$-test for organic carbon (Corg), soil penetration resistance (PR), soil water content (SWC), soil bulk density (BD), soil total porosity (TP), microporosity (Mic) and macroporosity (Mac) in the zones of the plot selected for the study

\begin{tabular}{|c|c|c|c|c|c|c|c|}
\hline Zone & Corg & PR & SWC & BD & $\mathbf{T P}$ & Mic & Mac \\
\hline & $\mathrm{g} \mathrm{dm}{ }^{-3}$ & $\mathrm{MPa}$ & $\mathrm{kg} \mathrm{kg}^{-1}$ & $\mathrm{Mg} \mathrm{m}^{-3}$ & 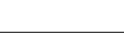 & $-\mathrm{m}^{3} \mathrm{~m}^{-3}$ & \\
\hline & & & & $0.00-0.10 \mathrm{~m}$ & & & \\
\hline $\mathrm{Z} 1$ & $34.94 \mathrm{Aa}^{*}$ & $1.50 \mathrm{Bb}$ & $0.46 \mathrm{Aa}$ & $1.05 \mathrm{Ba}$ & $0.61 \mathrm{Ab}$ & $0.51 \mathrm{Ab}$ & $0.09 \mathrm{Aa}$ \\
\hline $\mathrm{Z} 2$ & $32.80 \mathrm{Ba}$ & $1.65 \mathrm{Ab}$ & $0.42 \mathrm{Ba}$ & $1.12 \mathrm{Aa}$ & $0.58 \mathrm{Bb}$ & $0.52 \mathrm{Ab}$ & $0.06 \mathrm{Ba}$ \\
\hline Plot Mean & 33.87 & 1.58 & 0.44 & 1.09 & 0.59 & 0.52 & 0.08 \\
\hline Minimum & 22.78 & 0.98 & 0.38 & 0.93 & 0.54 & 0.43 & 0.02 \\
\hline Maximum & 39.41 & 2.40 & 0.52 & 1.29 & 0.66 & 0.59 & 0.22 \\
\hline $\mathrm{SD}^{(1)}$ & 1.82 & 0.24 & 0.02 & 0.06 & 0.02 & 0.02 & 0.03 \\
\hline \multirow[t]{2}{*}{$\mathrm{CV}(\%)^{(2)}$} & 6.49 & 9.65 & 3.55 & 3.52 & 2.49 & 2.50 & 24.45 \\
\hline & & & & $0.10-0.20 \mathrm{~m}$ & & & \\
\hline $\mathrm{Z} 1$ & $32.66 \mathrm{Ab}$ & $2.33 \mathrm{Aa}$ & $0.47 \mathrm{Aa}$ & $1.01 \mathrm{Bb}$ & $0.64 \mathrm{Aa}$ & $0.56 \mathrm{Aa}$ & $0.08 \mathrm{Aa}$ \\
\hline $\mathrm{Z} 2$ & $28.54 \mathrm{Bb}$ & $2.32 \mathrm{Aa}$ & $0.43 \mathrm{Ba}$ & $1.13 \mathrm{Aa}$ & $0.61 \mathrm{Ba}$ & $0.55 \mathrm{Aa}$ & $0.06 \mathrm{Ba}$ \\
\hline Plot Mean & 30.60 & 2.33 & 0.45 & 1.07 & 0.62 & 0.55 & 0.07 \\
\hline Minimum & 19.84 & 1.63 & 0.39 & 0.86 & 0.55 & 0.47 & 0.01 \\
\hline Maximum & 38.47 & 3.12 & 0.54 & 1.27 & 0.70 & 0.62 & 0.14 \\
\hline $\mathrm{SD}$ & 1.50 & 0.24 & 0.02 & 0.06 & 0.02 & 0.03 & 0.03 \\
\hline CV (\%) & 6.34 & 6.71 & 4.22 & 4.07 & 3.21 & 4.32 & 21.62 \\
\hline
\end{tabular}

*Means followed by different letters indicate significant difference $(\mathrm{p}<0.05)$ by Student's $t$-test. Upper case letters compare zones in the same layer and lower case letters compare layers at same zone. ${ }^{(1)} \mathrm{SD}$ : standard deviation; ${ }^{(2)} \mathrm{CV}$ : coefficient of variation. 
properties which are directly related. In the $0.10-0.20$ $\mathrm{m}$ layer, there was no difference of $\mathrm{PR}$ between zones, but PR increased from the $0.00-0.10$ to the $0.10-0.20$ $\mathrm{m}$ layer in both. In areas where NT is consolidated, as in the case of this study, the soil tends to compact in the subsurface (0.07-0.15 m) (Silva et al., 2000; Stone \& Silveira, 2001). On the surface, the mobilization of the soil by furrower mechanisms during sowing contributes to lower $P R$ values, as does the higher Corg levels observed (Table 4), since they are inversely correlated to PR (Melo et al., 2008; Schiavo \& Colodro, 2012).

Although some papers cited PR thresholds for soybean and rice root growth close to $3.0 \mathrm{MPa}$ (Mielniczuk et al.,1985 - for rice; Beutler, 2003 - for soybean and rice), the most commonly cited values are between 2.0 and $2.5 \mathrm{MPa}$ (Taylor et al., 1966), and $2.0 \mathrm{MPa}$ is the most cited threshold (Imhoff et al., 2000; Lapen et al., 2004). Therefore, the PR in Z1 and Z2 was potentially limiting for root growth in the $0.10-0.20$ m layer, with means close to $2.3 \mathrm{MPa}$. This was aggravated by the fact that soil SWC was high during the PR evaluations for Z1 and Z2 (0.43 and $0.47 \mathrm{~kg} \mathrm{~kg}^{-1}$ ), since a lower SWC would raise the PR values. Indeed, soil limitations must have been more restrictive in Z2 than in Z1 for the wheat crop in 2010, since $P R$ in the $0.00-0.10 \mathrm{~m}$ layer, measured in moist soil, was higher in $\mathrm{Z} 2$ than $\mathrm{Z} 1$. But figure 1 shows below-average rainfall in the months of wheat cultivation, leading to dry soil, and consequently, greatly increased PR.

Low variability was also recorded for BD in both soil layers, and the values decreased from $0.00-0.10$ to $0.10-0.20 \mathrm{~m}$ in $\mathrm{Z} 1$, but did not change significantly in Z2, which in turn had significantly higher values than Z1 in both layers. However, none of the BD values reached the critical limit of $1.30 \mathrm{Mg} \mathrm{m}^{-3}$ proposed by Reinert \& Reichert (2001) for clayey soils (as that investigated in this study). Accordingly, the data dispersion for TP and Mic of soil porosity was low and moderate for Mac (Table 4).

In both soil layers, TP and Mac were lower in Z2 than Z1, but no significant difference between zones was observed for Mic. With regard to the depth ranges, the Mic values in both zones were higher in 0.00-0.10 than in $0.10-0.20 \mathrm{~m}$, with no changes in Mac values, showing that the increase in TP observed in the deeper layer occurred due to increased Mic. The data also revealed a high Mic/Mac ratio, with Mic values always above $0.50 \mathrm{~m}^{3} \mathrm{~m}^{-3}$, which is 5.5 to 9.2 times higher than those of Mac, as is typical for NT and more compacted soils. According to Tormena et al. (2002), Mac is restrictive to crops when below $0.10-0.15 \mathrm{~m}^{3} \mathrm{~m}^{-3}$, due to its role in soil aeration, but this limit cannot be seen as ultimate, but depends on the soil species and biological activity. In this study, the highest mean value observed for Mac was $0.09 \mathrm{~m}^{3} \mathrm{~m}^{-3}$, in Z1 (0.00$0.10 \mathrm{~m}$ layer), while the lowest was $0.06 \mathrm{~m}^{3} \mathrm{~m}^{-3}$, in the same soil layer in $\mathrm{Z} 2$.
A combined increase in $\mathrm{BD}$ and $\mathrm{PR}$ was found with increasing soil depth, followed by decreased TP at the expense of Mac. Z2 was the zone where the soil physical conditions were potentially more restrictive to crops. Although the BD values were below the critical limit proposed by Reinert \& Reichert (2001), Mac remained below $0.10-0.15 \mathrm{~m}^{3} \mathrm{~m}^{-3}$, highlighting the poor distribution of pores in the different size classes. These results are in agreement with those of Amado et al. (2009), also in zones with contrasting yield, who confirmed that soil compaction and available water capacity are the most relevant soil physical properties for crop yield variation.

The variability of WIC data (Table 5) was moderate, but CV values were lower than those found by Miguel et al. (2009) in a Red Yellow Argisol (65$118 \%$ ), and by Scherpinski et al. (2010) in a dystrophic Red Latosol (91\%). The results are in agreement with the results in table 4 , since the WIC in Z1 was almost $30 \%$ higher than in $\mathrm{Z} 2$. This is probably related to the higher Mac in Z1, also almost $30 \%$ higher than in Z2, in the mean of both soil layers.

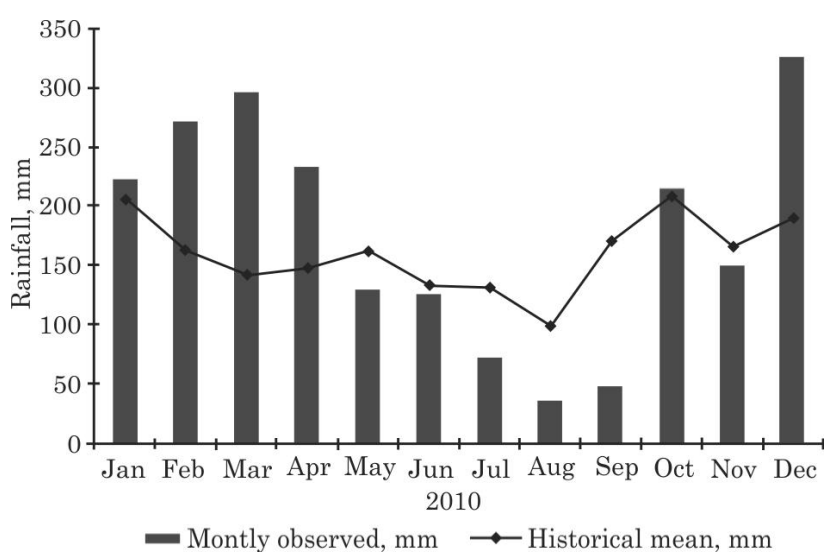

Figure 1. Historical mean of monthly rainfall (19762010) at the IAPAR weather station in Guarapuava, PR, and monthly observed (pluviometer) rainfall at the farm (Reserva do Iguaçu, PR) in 2010. Source: IAPAR (2011).

Table 5. Descriptive statistics and Student's $t$-tests for water infiltration capacity (WIC) of the soil in the zones of the plot selected for the study

\begin{tabular}{|c|c|c|c|c|c|}
\hline Zone & Mean & Minimum & Maximum & $\mathbf{S D}^{(1)}$ & $\mathbf{C V}^{(2)}$ \\
\hline & & $\mathrm{mm}$ & & & $\%$ \\
\hline $\mathrm{Z} 1$ & $56.11 \mathrm{~A}^{*}$ & 30.26 & 90.79 & 18.03 & 32 \\
\hline $\mathrm{Z} 2$ & 38.97 B & 30.26 & 70.62 & 13.21 & 34 \\
\hline Plot mean & 47.54 & 30.26 & 90.79 & 21.05 & 34 \\
\hline
\end{tabular}

${ }^{(1)} \mathrm{SD}$ : standard deviation; ${ }^{(2)} \mathrm{CV}$ : coefficient of variation. *Means followed by different letters indicate significant difference $(p<0.05)$ by Student's t-test. 
Although no direct correlation was observed between WIC and Mac, Pott \& De Maria (2003), using a permeameter in different textured soils, detected a positive correlation of WIC with TP and negative correlation of WIC with BD. According to Silva et al. (2008), decreased Mac has a great effect on the water infiltration capacity and on root development, especially in clay soils. Santi (2007), on the other hand, working with a soil under NT, concluded that the water infiltration of the soil was one of the most relevant soil physical properties for crop yield.

The reasons for the more restrictive soil physical conditions to plants in Z2 than in Z1 are possibly the same reasons that resulted in higher Corg levels in Z1 in both soil layers (Table 3), despite the small distance between zones (about 1,500 m). Assuming a homogeneous field management (equal for Z1 and Z2), the lower Corg content in Z2 may have been the result of the lower residue production by crops in this zone, consistent with the lower crop yields, as shown by the yield maps (Tables 1 and 2). One reason is that $\mathrm{Al}^{3+}$, analyzed a posteriori, was significantly higher in the subsurface of Z2 $\left(0.79 \mathrm{cmol}_{\mathrm{c}} \mathrm{dm}^{-3}\right)$ than of Z1 $\left(0.17 \mathrm{cmol}_{\mathrm{c}} \mathrm{dm}^{-3}\right)$, possibly restricting root growth and water and nutrient uptake, and consequently reducing plant growth in Z2 (unpublished data). In the NT management, lime is applied to the soil surface without incorporation, explaining why the difference in $\mathrm{Al}^{3+}$ between zones was observed in the surface layer only, since the conditions for lime dissolution and $\mathrm{Al}^{3+}$ neutralization in the deeper layer may have been less favorable in Z2, considering a soil with lower Corg, higher BD, lower porosity and lower water infiltration.

Conditions prior to soil use or details of the use itself may also have contributed to these differences. Despite the similarities between $\mathrm{Z} 1$ and Z2 in relation to slope and landscape position (shoulder position), Z2 is located in a more extreme position not only of the plot, but also of the farm, in a transition from prominent higher to lower positions, where the farm border is marked by eucalyptus. Therefore, although the soils were similar in the upper layers, there may be chemical, physical and/or hydrological differences in the deeper profile layers. Moreover, in addition to what has already been said, the border areas of large farms, farther away from the administrative headquarters, are negatively affected by operational problems, e.g., these areas are the last to be sown, so if all fertilizer is consumed before, fertilization will be incomplete, as similarly occurs with limestone or other inputs (seeds, pesticides etc).

A simple linear correlation matrix was established between the variables studied on the plot (Table 6). In the 0.00-0.10 m layer, except for Mic, all soil physical properties were significantly correlated to wheat GY. According to Callegari-Jacques (2003), the correlation was considered weak $(r<0.30)$ for GY x Mac $\left(0.21^{*}\right)$ and moderate $(0.30 \mathrm{~d}$ " $\mathrm{r}<0.60)$ in all other cases: GY x PR $\left(-0.33^{* *}\right)$, GY x SWC $\left(0.30^{* *}\right)$, GY x BD $\left(-0.32^{* *}\right)$, GY $x$ TP $\left(0.33^{* *}\right)$ and GY $x$ WIC $\left(0.31^{* *}\right)$. The results were similar in the $0.10-0.20 \mathrm{~m}$ layer: a weak

Table 6. Simple linear correlation matrix between variables studied in the plot, considering the evaluated soil layers

\begin{tabular}{|c|c|c|c|c|c|c|c|c|c|}
\hline & $\mathbf{G} \mathbf{Y}^{(\mathbf{1})}$ & Corg & PR & SWC & BD & $\mathbf{T P}$ & Mic & Mac & WIC \\
\hline \multicolumn{10}{|c|}{$0.00-0.10 \mathrm{~m}$} \\
\hline Corg & -0.14 & 1 & & & & & & & \\
\hline PR & $-0.33^{* *}$ & $-0.21^{*}$ & 1 & & & & & & \\
\hline SWC & $0.30^{* *}$ & 0.13 & $-0.28^{* *}$ & 1 & & & & & \\
\hline $\mathrm{BD}$ & $-0.32^{* *}$ & $0.28^{* *}$ & $0.45^{* *}$ & $-0.28^{* *}$ & 1 & & & & \\
\hline $\mathrm{TP}$ & $0.33^{* *}$ & $-0.26^{* *}$ & $-0.44^{* *}$ & $0.28^{* *}$ & $-0.99^{* *}$ & 1 & & & \\
\hline Mic & -0.10 & 0.07 & 0.13 & -0.10 & 0.20 & -0.19 & 1 & & \\
\hline Mac & $0.21^{*}$ & $-0.22^{*}$ & $-0.33^{* *}$ & $0.21^{*}$ & $-0.52^{* *}$ & $0.50^{* *}$ & $-0.32^{* * *}$ & 1 & \\
\hline WIC & $0.31^{* *}$ & 0.05 & $-0.44^{* *}$ & 0.09 & $-0.39^{* *}$ & $0.39^{* *}$ & -0.03 & $0.28^{* *}$ & 1 \\
\hline \multicolumn{10}{|c|}{$0.10-0.20 \mathrm{~m}$} \\
\hline Corg & 0.05 & 1 & & & & & & & \\
\hline $\mathrm{PR}$ & $-0.34^{* *}$ & -0.09 & 1 & & & & & & \\
\hline SWC & $0.30^{* *}$ & 0.02 & $-0.25^{*}$ & 1 & & & & & \\
\hline $\mathrm{BD}$ & $-0.29^{* *}$ & 0.05 & $0.60^{* *}$ & $-0.21^{*}$ & 1 & & & & \\
\hline $\mathrm{TP}$ & $0.28^{* *}$ & -0.05 & $-0.59^{* *}$ & $0.21^{*}$ & $-0.99^{* * *}$ & 1 & & & \\
\hline Mic & 0.09 & 0.10 & $0.37^{* *}$ & 0.15 & $-0.51^{* *}$ & $0.51^{* *}$ & 1 & & \\
\hline Mac & $0.20^{*}$ & -0.16 & $-0.24^{*}$ & 0.06 & $-0.51^{* *}$ & $0.51^{* * *}$ & $-0.48^{* * *}$ & 1 & \\
\hline WIC & $0.33^{* *}$ & 0.10 & $-0.45^{* *}$ & 0.17 & $-0.65^{* *}$ & $0.65^{* *}$ & $0.38^{* * *}$ & $0.28^{* *}$ & 1 \\
\hline
\end{tabular}

${ }^{(1)}$ GY: wheat grain yield; Corg: organic carbon; PR: soil penetration resistance; SWC: soil water content; BD: soil density; TP: soil total porosity; Mic: soil microporosity; Mac: macroporosity; WIC: water infiltration capacity of the soil. ** and * indicate significance at 1 and $5 \%$ probability, respectively. 
correlation also for GY x Mac $(0.20 *), \mathrm{GY} \times \mathrm{BD}(-0.29 * *)$ and GY x TP (0.28**), and moderate for GY x PR $\left(-0.34^{* *}\right)$, GY $x$ SWC $\left(0.30^{* *}\right)$ and GY x WIC $\left(0.33^{* *}\right)$, whereas the correlation of these last three soil physical properties in the $0.00-0.20 \mathrm{~m}$ layer with crop yield is noteworthy, in agreement with Imhoff et al. (2000), Hoad et al. (2001), Santi (2007) and Corrêa et al. (2009).

The results also show a moderate correlation for PR $x$ BD $\left(0.45^{* *}\right.$ and $\left.0.60^{* *}\right)$ and PR $\times$ WIC $\left(-0.44^{* *}\right.$ and $-0.45^{* *}$ ) in the $0.00-0.10$ and $0.10-0.20 \mathrm{~m}$ layers, respectively, confirming that the variations in soil bulk density occur due to changes in soil structure, with a directly proportional influence on soil mechanic resistance and an inversely proportional influence on water infiltration into the soil.

\section{CONCLUSIONS}

1. The soil physical conditions were more limiting to crops in the zone of lower yield potential.

2 . The wheat yield was negatively correlated with soil penetration resistance and bulk density, and positively correlated with the gravimetric water content in the field, total porosity, macroporosity and water infiltration capacity water of the soil.

\section{ACKNOWLEDGEMENTS}

The authors thank the agronomist Pellisson Kaminski for his help and the agrobusiness company Reinhofer Group, for granting access to the area, as well as for the support and information provided for the study.

\section{LITERATURE CITED}

AMADO, T.J.C.; PES, L.Z.; LEMAINSKI, C.L. \& SCHENATO, R.B. Atributos químicos e físicos de Latossolos e sua relação com os rendimentos de milho e feijão irrigados. R. Bras. Ci. Solo, 33:831-843, 2009.

ARAÚJO, R. Avaliação da qualidade do solo em áreas sob diferentes usos. Brasília, Universidade de Brasília, 2004. 77p. (Dissertação de Mestrado)

ASSISTAT. Assistência estatística. Versão 7.6 beta, 2011.

BHERING, S.B. \& SANTOS, H.G. Mapa de solos do Estado do Paraná: Legenda atualizada. Rio de Janeiro, Embrapa/ IAPAR, 2008. 74p.

BEUTLER, A.N. Efeito da compactação do solo e do conteúdo de água nas características agronômicas de soja e arroz de sequeiro. Jaboticabal, Universidade Estadual Paulista, 2003. 135p. (Tese de Doutorado)
BEUTLER, A.N.; CENTURION, J.F.; MENGATTO, L.H.; ALVES, J.B. \& WAGNER, G.P.C. Impacto do tráfego de máquinas na qualidade física do solo e produtividade de milho em Argissolo. Acta Sci. Agron., 31:359-364, 2009.

BLAINSKI, E.; GONÇALVES, A.C.A.; TORMENA, C.A.; FOLEGATTI, M.V. \& GUIMARÃES, R.M.L. Intervalo hídrico ótimo num Nitossolo Vermelho distroférrico irrigado. R. Bras. Ci. Solo, 33:273-281, 2009.

BLAKE, G.R. \& HARTGE, K.H. Bulk density. In: KLUTE, A., ed. Methods of soil analysis: Physical and a mineralogical methods. Madison, American Society of Agronomy, 1986. p.363-375.

BUSSCHER, W.J. Adjustment of flat-tipped penetrometer resistance data to common water content. Trans. Am. Soc. Agron. Eng., 33:519-524, 1990.

BUSSCHER, W.J.; BAUER, P.J.; CAMP, C.R. \& SOJKA, R.E. Correction of cone index for soil water content differences in a coastal plain soil. Soil Till. Res., 43:205-217, 1997.

CALLEGARI-JACQUES, S.M. Bioestatística: Princípios e aplicações. Porto Alegre, Artmed, 2003. 365p.

CERETTA, C.A.; BASSO, C.J.; FLECHA, A.M.T.; PAVINATO, P.S.; VIEIRA, F.C.B. \& MAI, M.E.M. Manejo da adubação nitrogenada na sucessão aveia preta/milho, no sistema plantio direto. R. Bras. Ci. Solo, 26:163-171, 2002.

CHERUBIN, M.R.; SANTI, A.L.; BASSO, C.J.; EITELWEIN, M.T. \& VIAN, A.L. Variabilidade da resistência a penetração do solo em função da dimensão da malha amostral. R. Plantio Direto, 125:4-9, 2011.

CORRÊA, A.N.; TAVARES, M.H.F. \& URIBE-OPAZO, M.A. Variabilidade espacial de atributos físicos do solo e seus efeitos sobre a produtividade do trigo. Semina: Ci. Agron., 30:81-94, 2009.

DANIELSON, R.E. \& SUTHERLAND, P.L. Porosity. In: KLUTE, A., ed. Methods of soil analysis. 2.ed. Madison, American Society of Agronomy, 1986. p.443-461.

DERPSCH, R.; FRIEDRICH, T.; KASSAM, A. \& HONGWEN, L. Current status of adoption on no-till faming in the world and some of its main benefits. Inter. J. Agric. Biol. Eng., 3:1-26, 2010.

DODERMANN, A. \& PING, J.L. Geostatistical integration of yield monitor data and remote sensing improves yield maps. Agron. J., 96:285-297, 2004.

EMPRESA BRASILEIRA DE PESQUISA AGROPECUÁRIA EMBRAPA. Serviço Nacional de Levantamento e Conservação do Solo. Manual de métodos de análise de solos. 2.ed. Rio de Janeiro, Embrapa Solos, 1997. 212p.

EMPRESA BRASILEIRA DE PESQUISA AGROPECUÁRIA EMBRAPA. Embrapa Milho e Sorgo. Sistemas de produção: Cultivo do milho. 4.ed. 2008a. Available: <http:/ /www.cnpms.embrapa.br/publicacoes/milho/index.htm>. Accessed: Sept. 5, 2011.

EMPRESA BRASILEIRA DE PESQUISA AGROPECUÁRIA EMBRAPA. Embrapa Trigo. Informações técnicas para a safra 2009: Trigo e triticale. Passo Fundo, Embrapa, 2008b. $172 p$. 
EMPRESA BRASILEIRA DE PESQUISA AGROPECUÁRIA EMBRAPA. Embrapa Trigo. Indicações técnicas para a produção de cevada cervejeira nas safras 2009 e 2010. Passo Fundo, Embrapa, 2009. 100p.

GIAROLA, N.F.B.; BRACHTVOGEL, E.L.; FONTANIVA, S.; PEREIRA, R.A. \& FIOREZE, S.L. Cultivares de soja sob plantio direto em Latossolo Vermelho compactado. Acta Sci. Agron., 31:641-646, 2009.

GUIMARÃES, R.M.L. Indicadores quantitativos e semiquantitativos da qualidade física do solo. Maringá, Universidade Estadual de Maringá, 2011. 102p. (Tese de Doutorado)

HOAD, S.P., RUSSELL, G., LUCAS, M.E., \& BINGHAM, I.J. The management of wheat, barley, and oat root systems. Adv. Agron., 74:193-246, 2001.

IMHOFF, S.; SILVA, A.P. \& TORMENA, C.A. Aplicações da curva de resistência no controle da qualidade física de um solo sob pastagem. Pesq. Agropec. Bras., 35:1493-1500, 2000 .

INSTITUTO AGRONÔMICO DO PARANÁ - IAPAR. Estações meteorológicas: Média históricas em estações do IAPAR. Available: <http://www.iapar.br/arquivos/Image/ monitoramento/Medias_Historicas/Guarapuava.htm>. Accessed: Nov. 20, 2011.

INSTITUTO AGRONÔMICO DO PARANÁ - IAPAR. Cartas Climáticas do Paraná. Versão 1.0. 2000. CD-ROM

ISLAN, K.R. \& WEIL, R.R. Soil quality indicator properties in mid-Atlantic soils as influenced by conservation management. J. Soil Water Conserv., 55:69-79, 2000.

KIEHL, E.J. Manual de edafologia: Relações solo-planta. São Paulo: Agronômica Ceres, 1979. 246p.

LAPEN, D.R.; TOPP, G.C.; GREGORICH, E.G. \& CURNOE, W.E. Least limiting water range indicator of soil quality and corn production, eastern Ontario, Canada. Soil Till. Res., 78:151-170, 2004.

LETEY, J. Relationship between soil physical properties and crop production. Adv. Soil Sci., 1:277-294, 1985.

LIRA, S.A. Análise de correlação: Abordagem teórica de construção dos coeficientes com aplicações. Curitiba, Universidade Federal do Paraná, 2004. 209p. (Dissertação de Mestrado)

LOPES, A.S.; WIETHÖLTER, S.; GUIMARÃES, L.R.G. \& SILVA, C.A. Sistema plantio direto: Bases para o manejo da fertilidade do solo. São Paulo, Associação Nacional para Difusão de Adubos, 2004. 115p.

MAGGIAN, R.C.; RIBEIRO, R.G. \& FELIPE, F.I. Análise da rentabilidade da cultura do trigo na região de Guarapuava-PR. In: CONGRESSO DA SOCIEDADE BRASILEIRA DE ECONOMIA, SOCIOLOGIA E ADMINISTRAÇÃO RURAL (SOBER), 68., Campo Grande, 2010. Anais... Campo Grande, Universidade Católica Dom Bosco, 2010. 18p.
MELO, R.O.; PACHECO, E.P.; MENEZES, J.C. \& CANTALICE, J.R.B. Susceptibilidade à compactação e correlação entre as propriedades físicas de um Neossolo sob vegetação de caatinga. Caatinga, 21:12-17, 2008.

MERCANTE, E.; URIBE-OPAZO, M.A. \& SOUSA, E.G. Variabilidade espacial e temporal da resistência mecânica do solo à penetração em áreas com e sem manejo químico localizado. R. Bras. Ci. Solo, 27:1149-1159, 2003.

MIELNICZUK, J.; CARPENEDO, V. \& PEDO, F. Desenvolvimento de raízes em solos compactados. Lav. Arroz., 38:42-43, 1985.

MIGUEL, F.R.M.; VIEIRA, S.R. \& GREGO, C.R. Variabilidade espacial da infiltração de água em solo sob pastagem em função da intensidade de pisoteio. Pesq. Agropec. Bras., 44:1513-1519, 2009.

MULLA, D. J. \& BHATTI, A.U. An evaluation of indicator properties affecting spatial patterns in $\mathrm{N}$ and $\mathrm{P}$ requirements for winter wheat yield. In: STAFFORD, J.V., ed. Precision agriculture '97: Spatial variability in soil and crop. Oxford, BIOS Science Publication, 1997. p.145-154.

PAVAN, M.A.; BLOCH, M.F.; ZEMPULSKI, H.C.; MIYAZAWA, M. \& ZOCOLER, D.C. Manual de análise química de solo e controle de qualidade. Londrina, IAPAR, 1992. 40p. (Circular, 76)

POTT, C.A. \& DE MARIA, I.C. Comparação de métodos de campo para determinação da velocidade de infiltração básica. R. Bras. Ci. Solo, 27:19-27, 2003.

POTT, C.A.; ROSIM, D.C. \& DE MARIA, I.C. Velocidade de Infiltração de Água - VIB: Para que serve e como avaliar essa importante propriedade dos solos. Agronômico, 57:27$28,2005$.

REICHERT, J.M.; SUZUKI, LE.A.S. \& REINERT, D.J. Compactação do solo em sistemas agropecuários e florestais: identificação, efeitos, limites críticos e mitigação. In: CERETTA, C.A.; SILVA, L.S. \& REICHERT, J.M., eds. Tópicos em ciência do solo. Viçosa, MG, Sociedade Brasileira de Ciência do Solo, 2007. v.5. p.49-134.

REINERT, D.J. \& REICHERT, J.M. Propriedades físicas de solos em sistema plantio direto irrigado. In: CARLESSO, R.; PETRY, M.; ROSA, G. \& CERETTA, C., eds. Irrigação por aspersão no Rio Grande do Sul. Santa Maria, 2001. p.114-131.

RESENDE, A.V. O sistema plantio direto proporciona maior eficiência no uso de fertilizantes. Sete Lagoas, Embrapa Milho e Sorgo, 2011. 23p. (Documentos/Embrapa Milho e Sorgo)

SANTI, A.L. Relações entre indicadores de qualidade do solo e a produtividade das culturas em áreas com agricultura de precisão. Santa Maria, Universidade Federal de Santa Maria, 2007. 175p. (Tese de Doutorado)

SCHERPINSKI, C.; URIBE-OPAZO, M.A.; VILAS BOAS, M.A.; SAMPAIO, S.C.; JOHANN, J.A. Variabilidade espacial da condutividade hidráulica e da infiltração da água no solo. Acta Sci. Agron., 32:7-13, 2010. 
SCHIAVO, J.A. \& COLODRO, G. Agregação e resistência à penetração de um Latossolo Vermelho sob sistema de integração lavoura-pecuária. Bragantia, 71:406-412, 2012.

SERRAT, B.M.; KRIEGER, K.I. \& MOTTA, A.C.V. Considerações sobre interpretação de análise de solo: com exemplos. In: LIMA, M.R.; SIRTOLO, A.E.; SERRAT, B.M.; WISNIEWSKI, C.; ALMEIDA, L.; MACHADO, M.A.M.; MARQUES, R.; MOTTA, A.C.V.; KRIEGER, K.I.; OLIVEIRA, A.C. \& FERREIRA, F.V., orgs. Diagnóstico e recomendações de manejo do solo: Aspectos teóricos e metodológicos. Curitiba, UFPR/Setor de Ciências Agrárias, 2006. p.125-142.

SILVA, A.P. \& KAY, B.D. Estimating the least limiting water range of soils from properties and management. Soil Sci. Soc. Am. J., 61:877-883, 1997.

SILVA, F.F.; FREDDI, O.S.; CENTURION, J.F.; ARATANI, R.G.; ANDRIOLI, F.F. \& ANDRIOLI, I. Propriedades físicas de um Latossolo Vermelho cultivado no sistema plantio direto. Irriga, 13:191-204, 2008.

SILVA, J.M.; PASSOS, A.L.R. \& BELTRÃO, F.A.S. Análise espacial da densidade, umidade e resistência mecânica do solo à penetração sob sistemas de cultivo. Eng. Amb., 6:103-118, 2009.

SILVA, V.R.; REINERT, D.J. \& REICHERT, J.M. Densidade do solo, atributos químicos e sistema radicular do milho afetados pelo pastejo e manejo do solo. R. Bras. Ci. Solo, 24:191-199, 2000.

SPSS, Inc. SPSS Statistics Base 18.0.1. User's guide. Chicago, 2009.
STONE, L.R. \& SILVEIRA, P.M. Efeitos do sistema de preparo e da rotação de culturas na porosidade e densidade do solo. R. Bras. Ci. Solo, 25:395-401, 2001.

TAYLOR, H.M.; ROBERSON, G.M. \& PARKER, J.J. Soil strength-root penetration relations for medium-to-coarse textured soil materials. Soil Sci., 102:18-22, 1966.

TAVARES FILHO, J.; FELTRAN, C.T.M.; OLIVEIRA, J.F.; ALMEIDA, E. \& GUIMARÃES, M.F. Atributos do solo determinantes para a estimativa do índice de estabilidade de agregados. Pesq. Agropec. Bras., 47:436-441, 2012.

TAVARES FILHO, J. \& RIBON, A.A. Resistência do solo à penetração em resposta ao número de amostras e tipo de amostragem. R. Bras. Ci. Solo, 32:487-494, 2008.

TORMENA, C.A.; BARBOSA, M.C.; COSTA, A.C.S. \& GONÇALVES, A.C.A. Densidade, porosidade e resistência à penetração em Latossolo cultivado sob diferentes sistemas de preparo do solo. Sci. Agric., 59:795-801, 2002.

TORMENA, C.A. \& ROLOFF, G. Dinâmica da resistência à penetração de um solo sob plantio direto. R. Bras. Ci. Solo, 20:333-339, 1996.

TORMENA, C.A.; ROLOFF, G. \& SÁ, J.C.M. Propriedades físicas do solo sob plantio direto influenciados por calagem, preparo inicial e tráfego. R. Bras. Ci. Solo, 22:301-309, 1998.

WARRICK, A.W. \& NIELSEN, D.R. Spatial variability of same physical properties of the soil. In: HILL, D., ed. Applications of soil physics. New York, Academic Press, 1980. p.319344. 